\title{
Classification of digital stitch lines in machine embroidery DOI: 10.35530/IT.072.05.202017
}

\section{ABSTRACT - REZUMAT}

\section{Classification of digital stitch lines in machine embroidery}

Despite the large application of the machine embroidery in textile and apparel design and high-tech clothing items, there is a lack of systematic arrangement of the digital stitch lines, used by embroidery machines and embroidery designers. Since 2010 information on embroidery stitch lines could be mostly found in the web sites of the embroidery machine manufacturers and software product manuals. However, in the instruction manuals the instruments for creating various embroidery objects are simply described without providing systematic information on the types of the stitch lines. Even more, different names of the stitch lines and different ways to achieve the same design are observed. Single authors offer their own classifications based entirely and logically on the stitches of the hand embroidery. Another group of authors relied on already developed techniques and strategies for digitizing stitches in various software products or took into account the final appearance of the stitch lines or their application. Our study aimed to develop a detailed and systematic classification of the digital stitch lines in the machine embroidery, which has not been presented in the literature.

Keywords: machine embroidering, classification, digital stitch lines, textiles, textile systems

\section{Clasificarea liniilor digitale de coasere în broderiile realizate pe mașinile de brodat}

În ciuda aplicării pe scară largă a broderiilor industriale în articolele de îmbrăcăminte uzuale și în cele de înaltă tehnologie, există o lipsă de dispunere sistematică a liniilor digitale de coasere, utilizate de mașinile de brodat și de proiectanții de broderie. Din 2010, informațiile despre liniile de coasere din broderii pot fi găsite în principal, pe site-urile web ale producătorilor de mașini de brodat și în manualele de produse software. Cu toate acestea, în manualele de instrucțiuni instrumentele pentru crearea diferitelor broderii sunt descrise simplist, fără a furniza informații sistematice despre tipurile de linii de coasere. În plus, sunt observate denumiri diferite ale liniilor de coasere și moduri diferite de a realiza același design. Anumiți autori oferă propriile lor clasificări bazate în întregime și în mod logic pe cusăturile utilizate în broderiile manuale. Un alt grup de autori s-a bazat pe tehnici și strategii deja dezvoltate pentru digitalizarea cusăturilor în diferite produse software sau au luat în considerare aspectul final al liniilor de coasere sau aplicația acestora. Studiul nostru a urmărit să dezvolte o clasificare detaliată și sistematică a liniilor digitale de coasere în broderiile realizate pe mașinile de brodat, care nu este prezentă în literatura de specialitate.

Cuvinte-cheie: broderie realizată pe mașina de brodat, clasificare, linii digitale de coasere, textile, sisteme textile

\section{INTRODUCTION}

The purpose of embroidery is to add an ornament to clothing, accessories, towels, bed linen, curtains, tablecloths, and other types of textile products. Very often, embroidery serves for advertising, used as logos, contains event information (for conferences, seminars, symposia), or sends different messages to people. The creation of embroidery was only manual for centuries, but with the Industrial Revolution, machine embroidery displaced on a large scale the hand embroidery. That is why embroidering can now be defined as a more sophisticated sewing process. Since 1980, when the first computer graphics of Wilcom minicomputer embroidery have been created, to date, the development of this group of textile machines has reached a high technological level [1]. Embroidery techniques are also used for the manufacturing of electronic textiles and conductive textile structures, allowing the connection between the textile system and electronic modules.
The research on the quality and application of embroidery is quite extensive. Several publications were dedicated to the accuracy of the shape and dimensions of the embroidery element [2-5]. A large area of research is dedicated to the ends-down of the embroidery machines and defects in the embroideries [6-12]. Another area of research involves the electronic textiles and high-tech clothing that are rapidly growing sectors in the textile and apparel industries. The embroideries are used as conductive systems, which are necessary for the best performing of the textile items and assuring their accuracy [13-20]. Despite the large application of the machine embroidery in textile and apparel design and high-tech clothing items, there is still a lack of systematic arrangement of the stitch lines, used by embroidery machines and embroidery designers. Our previous analysis [21] showed that the most comprehensive source of information on machine embroidery since 2010 could be found on the web sites of the leading embroidery machine's manufacturers and in the software manuals. Single authors [22] offer their own 
classifications based entirely and logically on the stitches of the hand embroidery, characterized by the application of a wide variety of techniques. However, in the machine-based embroidery, the needle passes only on one side of the fabric, and it is possible to obtain straight double lockstitches, typical for the lockstitch sewing machines, chain stitches and loose loops without knots. Another group of authors relied on already developed techniques and strategies for digitizing stitches in various software products to create machine embroidery designs [23]. Other authors took into account the final appearance of the stitch lines or their application [24].

The aim of our study was to develop and propose a general classification of the digital stitch lines for machine embroidery. The classification is based on the sequence of the stitch line formation, stitch line appearance, approaches for filling, and final application.

\section{FORMATION OF STITCH LINES IN MACHINE EMBROIDERY}

The principle of the embroidery machines' work is similar to that of the ordinary gripper sewing machine. The difference is that the fabric is embedded in an embroidery frame and moves into an $X Y$ plane after each needle puncture. There is no real change in the type of stitch or the way the needle and the graft threads cross, but the size and direction of the displacement before the needle punch can be controlled. This unified stitch, a point-to-point line, is

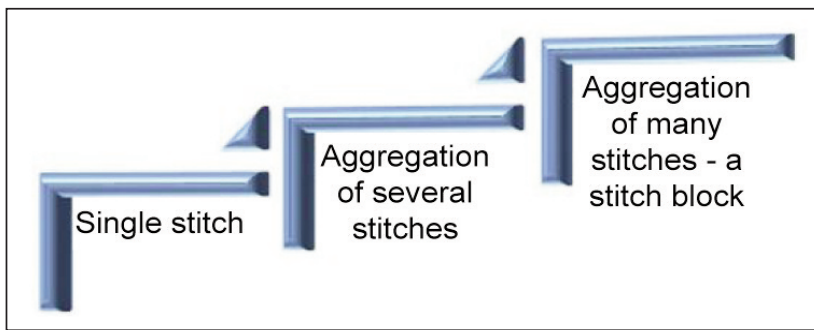

Fig. 1. Formation of the stitch lines in machine embroidery

the primary building block of the embroidery (figure 1). In addition, several building blocks can be stacked in a certain way to form a group of stitches, which in turn follow an arbitrary trajectory. The way of forming this combination of a small number of single stitches is inspired by hand embroidering.

When a significantly higher number of stitches are applied to form more sophisticated shapes (floral motifs, geometric patterns), then stitch blocks are used. Working with the stitch blocks, it is possible to define within the boundaries of an object: * the step and angle of the stitches, * the size of the motif itself, * the distance between the individual motifs in the $\mathrm{XY}$-direction.

\section{CLASSIFICATION OF STITCHES IN MACHINE EMBROIDERY}

Figure 2 shows the proposed classification of the stitches in the machine embroidery: each stitch and

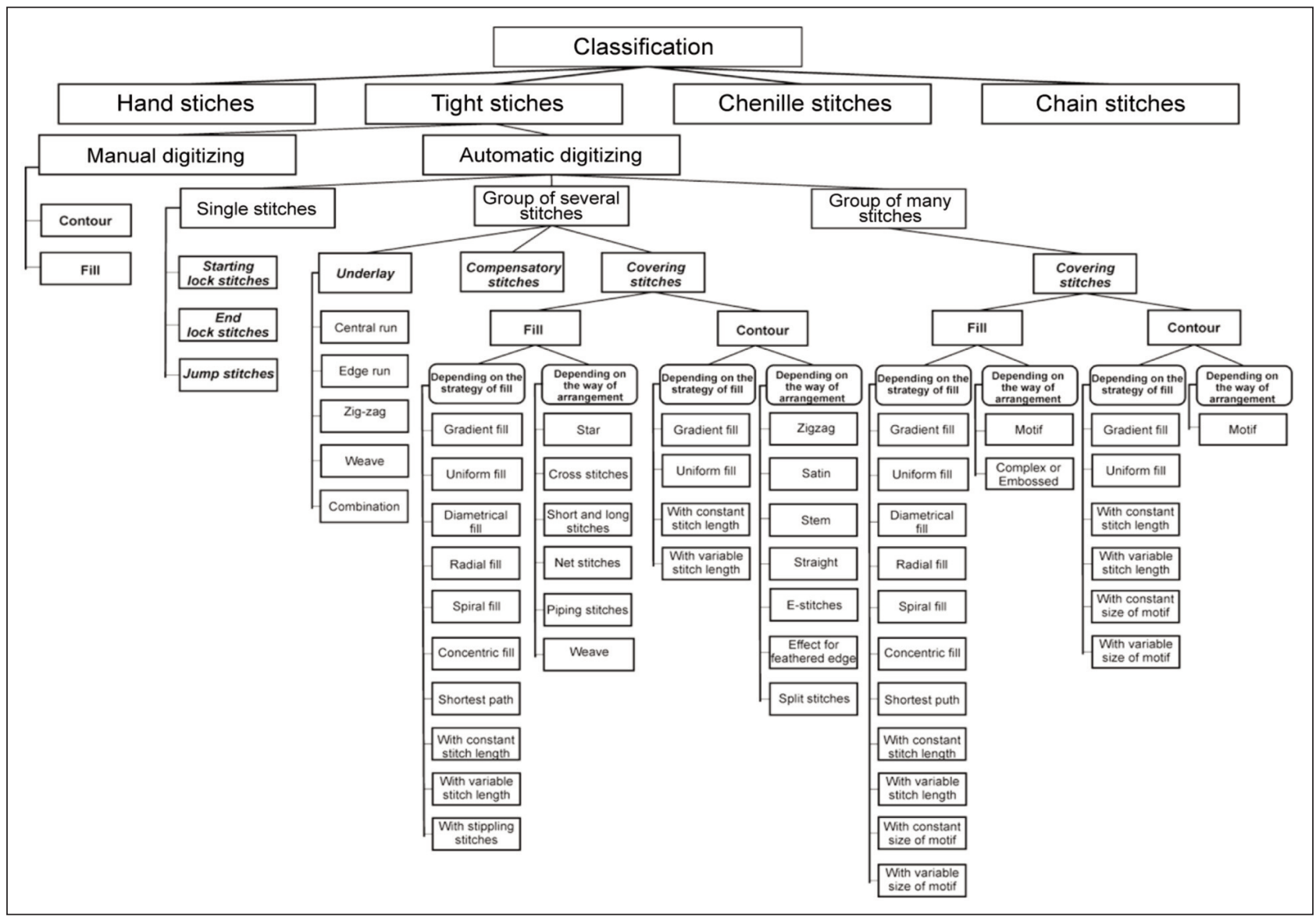

Fig. 2. Classification of the stitch lines in the machine embroidery 


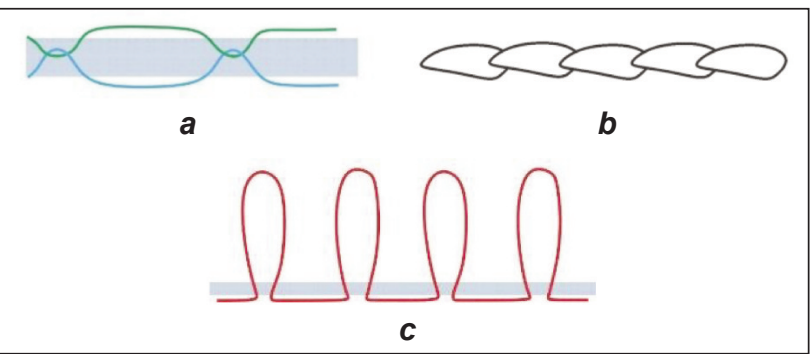

Fig. 3. Types of face covering stitches: $a$ - tight; $b$ - chain stitch; $c$ - loop

its place in the classification are discussed below. At this stage of development of the embroidery machines, the stitches that can be obtained are interlocking or tight (figure 3,a), imitating hand, chain stitches (figure $3, b$ ) and those with loops (figure 3,c). The result of applying the last type of stitches is a Chenille embroidery (figure 4), which is less common and is made using special needles with a hook. Embroidery machines that form hand and chain stitches are also rarely used.

According to the digitization method of the embroidery, the stitch lines obtained from tight stitches can be divided into two groups: manual and automatic digitizing.

\section{Manual digitizing}

In manual digitizing, the contour and filling stitches are the two main stitch lines. The contour stitch (figure 5) outlines the delineation of the object. The filling stitch (figure 6) is a surface stitch used to fill the embroidered object, parts of it, or the background. There is no specific stitch, which can be indicated as a "filling stitch", as the user himself chooses each step and direction of the single stitch.

\section{Automatic digitizing}

In automatic digitization the embroidery object is firstly divided into single stitches, a group of stitches and blocks.

\section{Single stitches}

Figure 7 illustrates the single stitches in an embroidery detail. Two types of single stitches can be distinguished:

- Strengthening stitches. These stitches are placed at the beginning and the end of the stitch line, being: * Starting lock stitch and * End lock stitch.

- Jumping stitches. They assure the transition from one object to another with (or without) the formation of stitch lines. In the modern machines, the program automatically generates the jumping stitches, following the embroidery sequence and objects' start and end. They can be stitched from one point to another or in the form of a straight stitch with a set pitch.

Group of several stitches

In accordance with their application in the embroidery design, the stitch rows that are formed by groups of several stitches are divided into three groups: underlay stitches, compensatory stitches, and covering stitches. The underlay stitch lines play a crucial role in machine embroidery, as the quality of the embroidery obtained depends on them. They remain hidden beneath the surface of the embroidery but assure the stability, volume, density, accuracy, and clear image of the embroidery. Calculating the exact number and type of the underlay stitches and their respective density is an essential step in the process of digitization. The basic rule is that the direction of the underlay stitch line must be at a different angle from that of the outer covering stitch lines to balance the structure and prevent the single stitches from sinking. The underlay stitches are of different types, namely: * Central Run (figure 8): a straight lock stitch line with trajectory following the centerline of the object. It is applied to objects with a small width (columns) or in combination with other types of underlay stitches. * Edge Run (figure 9): a straight lock stitch line for outlining the contours of the object. It is used for objects of small width or in combination with other

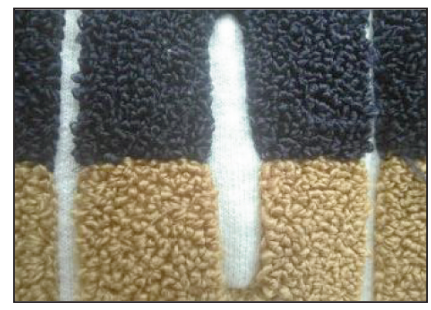

Fig. 4. Chenille embroidery

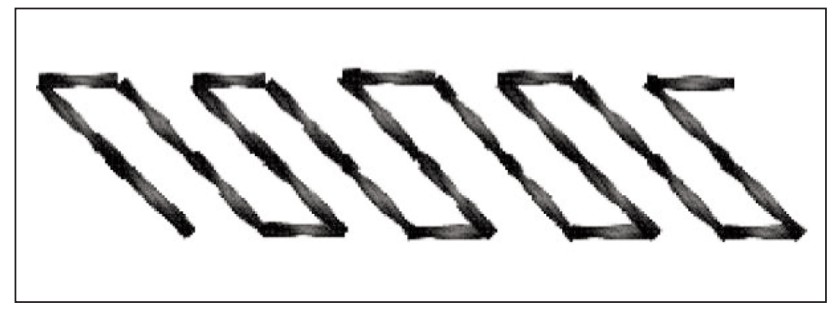

Fig. 5. Contour stitch

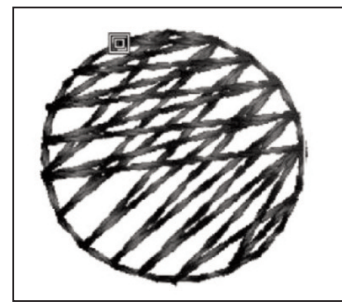

Fig. 6. Filling stitch

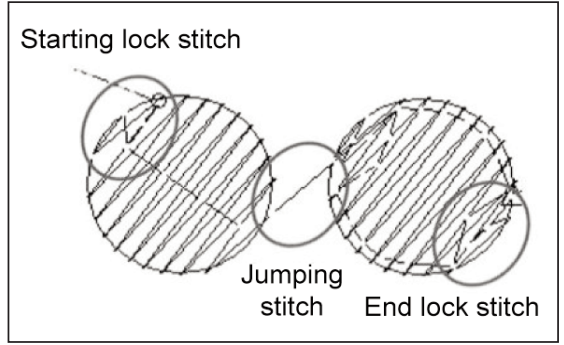

Fig. 7. Single stitches

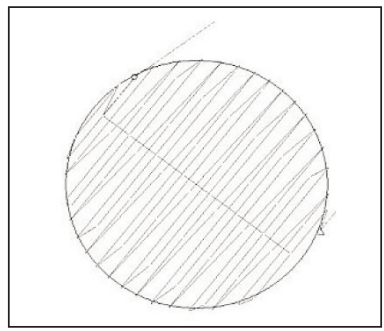

Fig. 8. Central run underlay stitch line

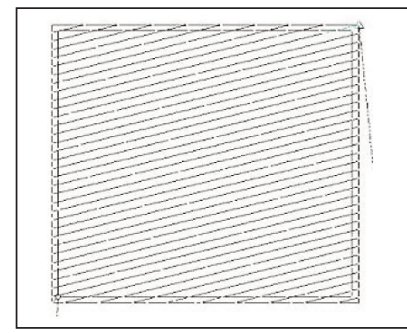

Fig. 9. Edge run underlay stitch line 


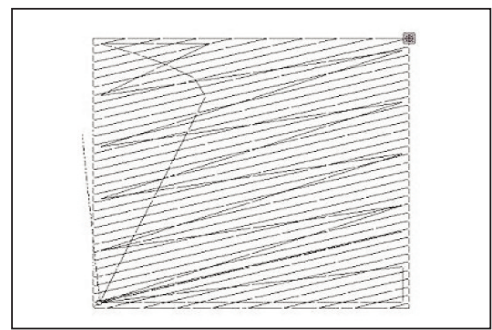

Fig. 10. Zigzag underlay stitch line

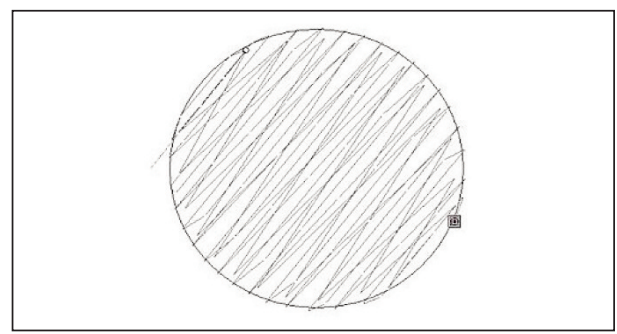

Fig. 11. Double Zigzag underlay stitch line

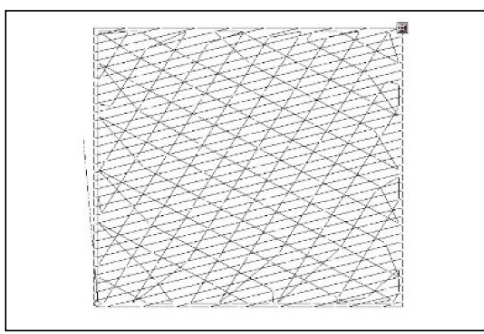

Fig. 12. Weave underlay stitch line types of underlay stitches. * Zigzag (figures 10 and 11 ): it is particularly suitable for objects, made with covering stitches. It can also be used in combination with other underlay stitches. * Weave (figure 12): Similarly to the zigzag stitch, it is used in objects, where covering stitches are applied. Suitable for combination with other types of underlay stitches.

The second group of stitches is called "compensatory", because they serve to compensate for possible differences in the sizes of the virtual and real embroidered objects that result from the fabric deformation. For example, when embroidering on cotton fabrics, about $2 \%$ stitches are added, which should cover the difference in the size obtained.

The third group, called "covering" stitches, can be divided into two sub-groups, depending on their role in the embroidery and the way of arrangement of the stitches: fill covering stitches and contour covering stitches. The first sub-group involves the stitches that fill the objects in the embroidery. They are used for embroidering large-area objects. The fill covering stitches are stacked close to one another at a certain angle so that complete surface coverage can be achieved. The density of the stitches can vary to achieve a number of effects.

The fill covering stitches give the embroidery a flat appearance and have less shine than the satin stitch line, but they can fill areas of much larger size without producing a wavy surface, which could be the case with satin. The stitch line can be changed by varying the distance and alignment of the individual stitches, as well as the length of the stitch.

Depending on the strategy of filling, the fill covering stitches can be for: * Gradient fill (figure 13): the object is divided into different zones, filled in with different densities of the stitch lines. The distribution of the zones can be various, depending on the object and the design vision: * Uniform fill (figure 14): the density of the stitches has a constant value for the whole object; * Diametrical fill (figure 15): the strategy is to follow the contour (diameter) of the object; * Radial fill (figure 16): the stitch line goes from the center to the contour of the object (following the radius); * Spiral fill (figure 17): the covering stitches follow a spiral line; * Concentric fill (figure 18): the covering paths are concentric circumferences; * Shortest path: this strategy is based on finding the shortest path for covering the object with a specific geometry; * Fill with constant stitch length: the filling is carried out with a constant value of the step of the stitch line; * Fill with variable stitch length (figure 19): a variable value of the step of the stitch line is used, according to the stitch line's trajectory; * Fill with stipping stitches (figure 20): this strategy is borrowed

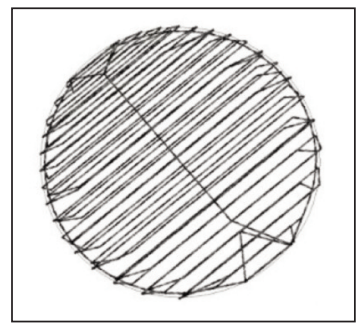

Fig. 13. Gradient fill (with weave)

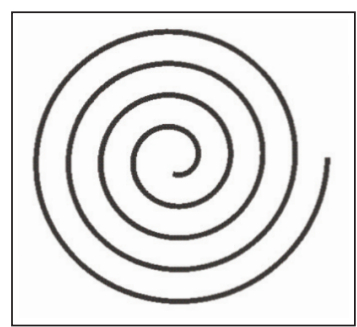

Fig. 17. Spiral fill

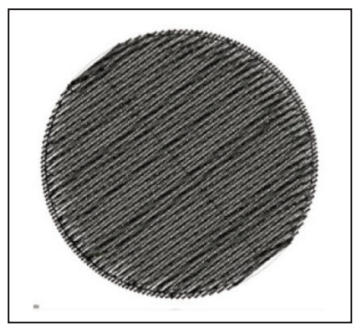

Fig. 14. Uniform fill (with weave)

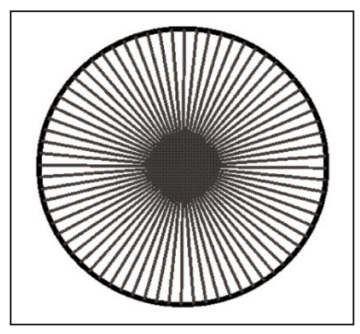

Fig. 15. Diametric fill

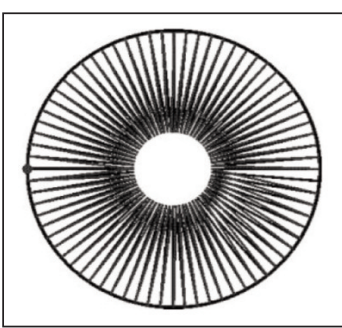

Fig. 16. Radial fill

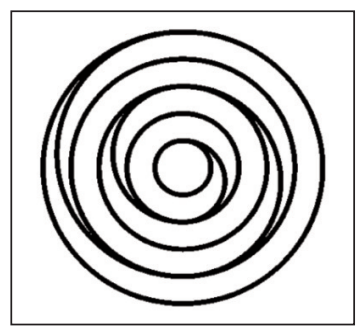

Fig. 18. Concentric fill

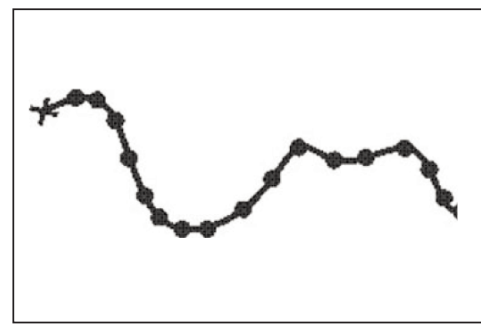

Fig. 19. Fill with variable stitch length

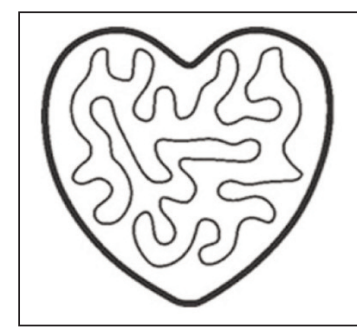

Fig. 20. Fill with stipping stitches 


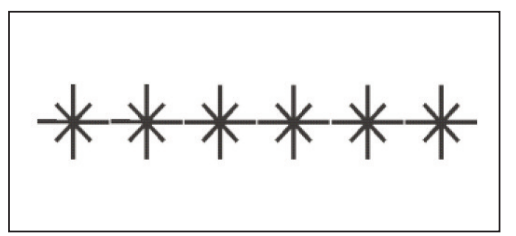

Fig. 21. Star stitch line

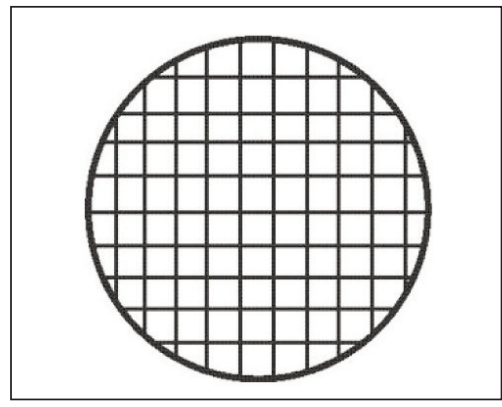

Fig. 24. Net stitch line

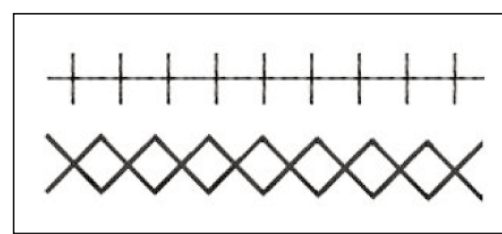

Fig. 22. Cross stitch line

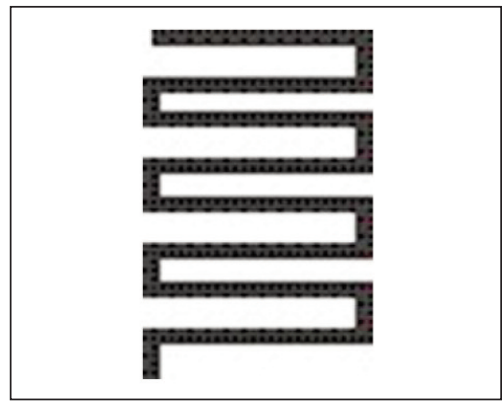

Fig. 25. Piping stitch line

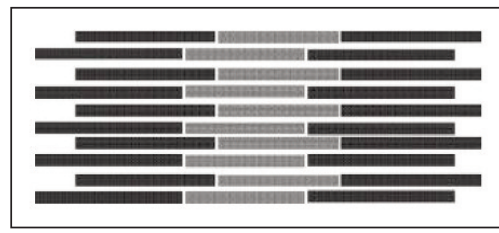

Fig. 23. Short and long stitch line

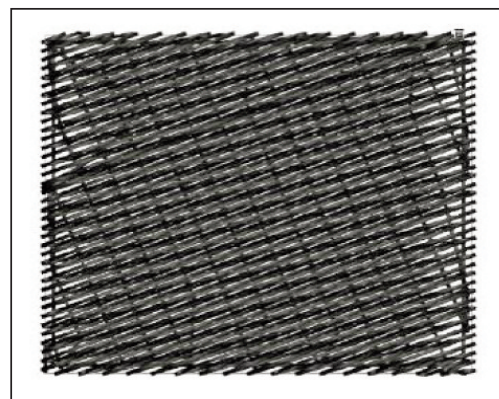

Fig. 26. Fill weave stitch line from the quilting and is applied when layers of a textile system are joined together. It is usually performed with a running stitch line, so that the zones, divided by the stitch line to have approx. the same width.

Depending on the way of the stitches arrangement, the fill covering stitches can be: * Star stitch line (figure 21): the stitch is borrowed from the hand embroidery; * Cross stitch line (figure 22): it is also typical for the hand embroidery; * Short and long stitch lines (figure 23): the alternation of short and long stitches creates a gradual overflow that has also root in the hand embroidery; * Net stitches (figure 24): these are new machine embroidery lines that form a net (mesh), 3D visual effects can be obtained using different dimensions of the squares; * Piping stitches (figure 25): a new stitch line, typical for the machine embroidery; *Weave (figure 26): a covering stitch line, also known as "tatami", used for large objects.

The second sub-group involves stitches, used for covering embroidery objects with a small width, up to $20 \mathrm{~mm}$. They involve:

- Satin stitch line (figure 27): The satin (or column) stitch line is hugely suitable for lettering and contouring. The single stitches are stacked side by side, following an arbitrary line, always remaining perpendicular to the axis. Theoretically, it is suitable for objects smaller than $20 \mathrm{~mm}$ (in width), but practically they should be less than $12 \mathrm{~mm}$. Otherwise, the stitches become loose and can be easily damaged. Designers use the satin to enhance the object's dimensions due to the better light reflection.

- Zigzag stitch line (figure 28): it differs from satin only in the density of the stitches.

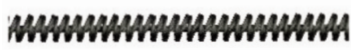

Fig. 27. Satin stitch line
64844444844844444

Fig. 28. Zigzag stitch line
- Stem stitch line: similar to satin but the embroidery path is at a certain angle concerning the single stitches.

- Straight stitch line: the straight lock stitch line usually consists of stitches of the same length, but through the software, the stitch length can be changed automatically when the shape of the contour is monitored. Different effects can be achieved by applying different stitching steps: the long stitches are shinier and smoother than the short ones that give a more rugged and tight embroidery look. The number of passes through an element can also vary to obtain thicker or thinner lines - single, double, or triple.

- E-stitches (figure 29): known as well as a "blanket stitch".

- Stitch line for feathered edge effect (figure 30): it creates a shading effect of the object, rough contours, and can be used for animal fur imitation.

- Split stitch line: it is similar to the stem stitch, with a more twisted appearance.

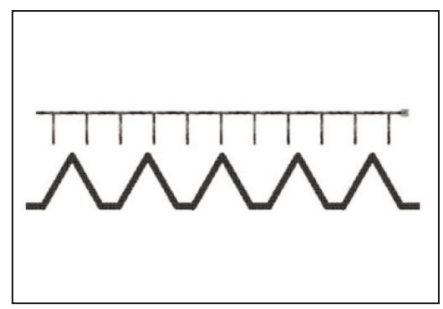

Fig. 29. E-stitches

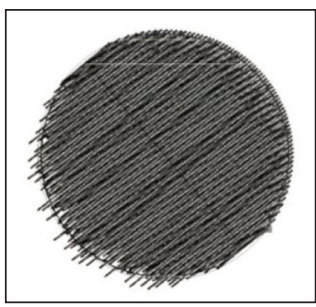

Fig. 30. Feathered edge effect
Group of many stitches (blocks)

The third group of automatically digitized embroidery stitch lines has the most complex organization of the stitches. The stitch lines form blocks and play the role of covering stitches, which form the contour of the embroidery objects or are used to fill them. 
The fill covering stitches are again divided into two groups. Depending on the strategy of fill, the same types of blocks of stitches can be defined as for groups of several stitches: gradient fill, uniform fill, diametrical fill, radial fill, spiral fill, concentric fill, shortest path fill, and fill with constant stitch length and variable stitch lengths. Only the fill with stipping stitches is missing. Instead, two new possibilities appear: * Blocks of stitch lines, based on motifs, with constant size of the motif (figure 31) and * Blocks of stitch lines, based on motifs, with variable size of the motif (figure 32).

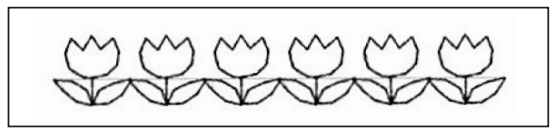

Fig. 31. Constant size motif filling

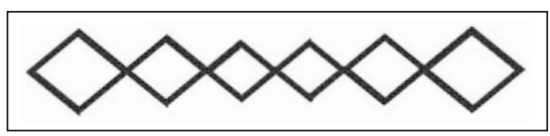

Fig. 32. Variable size motif filling

Depending on the way of arrangement, the blocks of fill stitches are: Motifs (figure 33): different motifs, organized in blocks, fill the surface of the object. Modern

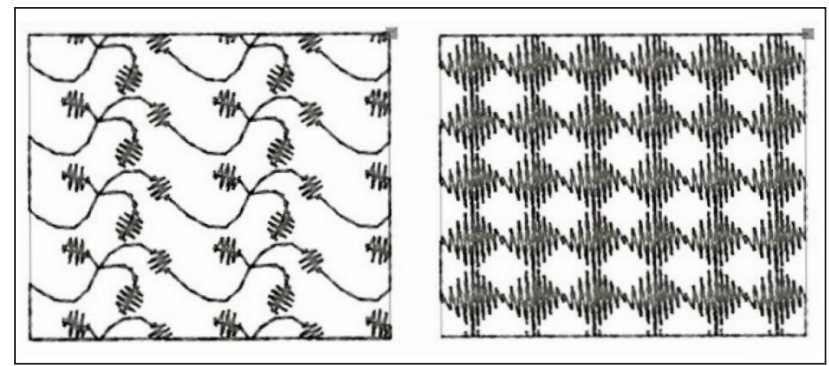

Fig. 33. Covering motifs

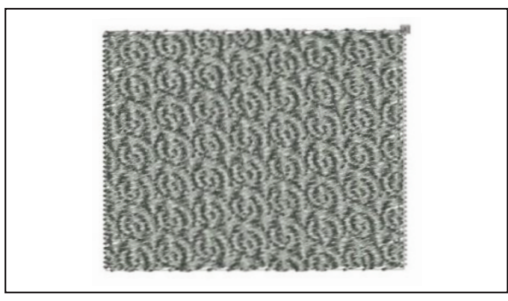

Fig. 34. Complex or emboss filling

software tools enable the creation of filling stitches in the form of smooth curved lines, resulting in the sense of increased contour and volume. Complex or embossed (figure 34): both the direction of the stitch rows and its density change horizontally and vertically. Thus, different visual effects are achieved.

Depending on the strategy of the fill, the contour covering stitch lines involve block stitches for gradient fill, uniform fill, stitch lines with constant and variable stitch length, as well as lines with constant or variable size of the motif, as in the case of fill covering stitches. It should be mentioned that some of patterns cannot be produced without stitching over existing stitches.

\section{CONCLUSIONS}

The proposed classification of the machine embroidery stitches allows a better understanding of the design abilities of different software products and embroidery machines. It helps both the learners and the experienced designers to orient in the possibilities for the creation of embroideries with a desired and unique look.

The classification can further be enlarged as the field of machine embroidering is among the fast-developing textile branches.

\section{ACKNOWLEDGEMENT}

The authors would like to thank the Research and Development Sector at the Technical University of Sofia for the financial support for the publishing of the present research

\section{REFERENCES}

[1] Sofronova, D., Opportunities of machine embroidery for creation of design interpretations, In: Proceedings of 20th Int. Conf. of the FPEPM, Sozopol, Bulgaria, 2015, 272-278

[2] Juciene, M., Radaviciene, S., Influence of embroidery threads on the accuracy of embroidery pattern dimensions, In: Fibres \& Textiles in Eastern Europe, 2012, 3, 92, 92-97

[3] Radaviciene, S., Juciene, M., Juchnevičienè, Ž., Čepukone, L., Vilumsone, A., Briedis, U., Baltina, I., Analysis of shape nonconformity between embroidered element and its digital image, In: Materials Science, 2014, 20, 1, 84-89

[4] Juchnevičienè, Ž., Juciene, M., Dobilaite, V., Saceviciene, V., Gulbiniene, A., The Research on the Accuracy of the Geometrical Parameters of the Closed-Circuit Embroidery Element, In: Materials Science, 2018, 24, 4, 453-549

[5] Juchnevičienè, Ž., Jucienè, M., Dobilaitè, V., Sacevičienè, V., Radavičienè, S., Analysis on the Conformity between the Closed-Circuit Embroidery Elements of Different Widths and the Digitally Designed Elements, Autex Research Journal, 2019, 250-256, https://doi.org/10.1515/aut-2018-0047

[6] Radaviciene, S., Juciene, M., Juchnevičienè, Ž., Čepukone, L., Kleveckas, T., Narviliene, V., The influence of the properties of embroidery threads on buckling of fabric inside of the embroidered element, In: Materials Science, 2012, 18, 4, 373-378

[7] Juciene, M., Radaviciene, S., Saceviciene, V., Adaškevicius, R., Petraitiene, S., The research on surface nonuniformity of textile systems, In: Int. Journal of Clothing Science and Technology, 2016, 28, 1, 36-46

[8] El-Kateb, S.N., An investigation of factors affect ends-down rate in embroidery machine, In: Journal of American Science, 2015, 11, 6, 39-42 
[9] Kuo, C.F.J., Juang, Y., A study on the recognition and classification of embroidered textile defects in manufacturing, In: Textile Research Journal, 2016, 86, 4, 393-408

[10] Sofronova, D., Angelova, R.A., Classification of the embroidery defects, In: Proceedings of 21st Int. Conf. of the Faculty of Power Engineering and Power Machines, Sozopol, Bulgaria, 2016, 196-201

[11] Wei, B., Hao, K., Tang, X. S., Ding, Y., A new method using the convolutional neural network with compressive sensing for fabric defect classification based on small sample sizes, In: Textile Research Journal, 2018, 0040517518813656

[12] Angelova, R.A., Sofronova, D., Nikolova, V., A case study on the defects in industrial manufacturing of embroidered textiles, In: Journal of Multidisciplinary Engineering Science and Technology, 2016, 3, 12, 2458, 9403

[13] Mecnika, V., Hoerr, M., Krievins, I., Jockenhoevel, S., Gries, T., Technical embroidery for smart textiles, In: Materials Science. Textile and Clothing Technology, 2014, 9, 56-63

[14] Zhang, L., Wang, Z., Volakis, J.L., Embroidered textile circuits for microwave devices, In: Proceedings of the 2012 IEEE International Symposium on Antennas and Propagation, 2012, 1-2

[15] Radavičiene, S., Jucienè, M., Sacevičiene, V., Sacevičius, R., Otas, K., Investigation and assessment of photoluminescent embroidered elements, In: Int. Journal of Clothing Science and Technology, 2014, 26, 1, 38-47

[16] Åkerfeldt, M., Lund, A., Walkenström, P., Textile sensing glove with piezoelectric PVDF fibers and printed electrodes of PEDOT: PSS, In: Textile Research Journal, 2015, 85, 17, 1789-1799

[17] Wang, Z., Lee, L.Z., Psychoudakis, D., Volakis, J.L., Embroidered multiband body-worn antenna for GSM/PCS/WLAN communications, In: IEEE Transactions on Antennas and Propagation, 2014, 62, 6, 3321-3329

[18] Simorangkir, R.B., Yang, Y., Esselle, K.P., Double-layer embroidery strategy for fabrication of textile antennas with improved efficiency, In: 17th International Symposium on Antenna Technology and Applied Electromagnetics (ANTEM), 2016, 1-2

[19] Briedis, U., Valisevskis, A., Grecka, M., Development of a smart garment prototype with enuresis alarm using an embroidery-machine-based technique for the integration of electronic components, In: Procedia Computer Science, 2017, 104, 369-374

[20] Juchnevičienè, Ž., Briedis, U., Vališevskis, A., Jucienè, M., Dobilaitè, V., Sacevičienè, V., Electrical conductivity of a closed-circuit embroidery element, In: Proceedings of the Estonian Academy of Sciences, 2018, 67, 2, 158-164

[21] Sofronova, D., Angelova, R.A., Analysis of the types of digital stitches in machine embroidery, In: Proceedings of 22nd Int. Conf. of FPEPM, Sozopol, Bulgaria, 2017, 132-136

[22] Start, B., Brokerage of embroidery capacity, In: Eurostitch Magazine, 2001, 9, 48, 34-39

[23] Ripka, G., Mychko, A., Deyneka, I., The analysis of machine embroidery stitches types classification, In: Teka Komisji Motoryzacji i Energetyki Rolnictwa, 2014, 14, 2

[24] Chernenko, D.A., Systematization of the design parameters of the automated embroidery and modeling of the deformation of the system "cloth-embroidery", PhD, Orel State Technical University, Russia, 2006, 120

\section{Authors:}

\section{DANIELA SOFRONOVA, RADOSTINA A. ANGELOVA}

Technical University of Sofia, Department of Textiles, 8 Kliment Ochridski Blvd., 1000, Sofia, Bulgaria e-mail: joy-angels@abv.bg

\section{Corresponding author:}

\section{DANIELA SOFRONOVA}

e-mail: dcholeva@tu-sofia.bg 